\title{
"DEBERES Y OBLIGACIONES DE LOS ESTADOS PARA COMBATIR LA IMPUNIDAD A LA LUZ DE LA JURISPRUDENCIA DE LA CORTE INTERAMERICANA DE DERECHOS HUMANOS"
}

\author{
DUTIES AND OBLIGATIONS OF STATES TO COMBAT \\ IMPUNITY IN THE LIGHT OF THE JURISPRUDENCE \\ OF THE INTER-AMERICAN COURT \\ OF HUMAN RIGHTS
}

ALFONSO CHACÓN MATA*

\section{Resumen}

El presente trabajo intenta definir las principales líneas jurisprudenciales con las que la Corte Interamericana de Derechos Humanos, ha venido definiendo el fenómeno de la Impunidad. El alcance es de corte jurídico, tratando de aportar al menos ocho líneas o temáticas, que ayuden a los Estados y operadores de justicia, a conocer cuando se encuentran ante situaciones de impunidad, previamente definidas por la misma Corte.

\section{Palabras Claves}

Impunidad- Justicia- Corte Interamericana de Derechos HumanosObligación de Investigar- Obligación de Combatir la Impunidad-.

* CHACÓN MATA, Alfonso, Profesor Facultad de Derecho de la Universidad de Costa Rica y Presidente del Comité Ético Científico de esa misma casa de estudios. Máster en Protección Internacional de los Derechos Humanos, Universidad Alcalá de Henares, España. Artículo recibido el 9 de octubre de 2017 y aceptado el 30 de noviembre de 2017.

Revista de Ciencias Sociales - Número 71 (2017) - Universidad de Valparáíso - ISSN 0716-7725-Valparáiso, Chile 


\begin{abstract}
This paper attempts to define the main lines of jurisprudence with which the Inter - American Court of Human Rights has been defining the phenomenon of impunity. The scope is of juridical court, trying to contribute at least eight lines or themes, that help the States and justice operators, to know when they are before situations of impunity, previously defined by the same Court.
\end{abstract}

\title{
Keywords
}

Impunity - Justice - Inter-American Court of Human Rights Obligation to Investigate - Obligation to Combat Impunity -.

\section{Introducción}

A lo largo de estas líneas, vamos a referirnos sobre una temática que supone el tratamiento jurisprudencial de un ámbito de enorme trascendencia, en la vivencia política del continente latinoamericano. En la dimensión de los fallos de la Corte Interamericana de Derechos Humanos, analizaremos los principales antecedentes de la impunidad como ausencia de castigo por ilícitos contra los derechos humanos, y la manera en que esta omisión supone un grave obstáculo para el derecho a la verdad, constituyéndose este derecho en un legado y antecedente para los familiares y sociedad política en general. Estamos ni más ni menos, ante el derecho a saber y conocer, que pasó para cada situación de violación particular de los derechos humanos. Sin duda el abordaje de este artículo es de índole jurídico, por lo que pretendemos realizar una breve explicación a la luz de los anales jurídicos, en el sentido que nos permita entender, de donde proviene el contexto de los Estados e instituciones judiciales, omisas y ajenas a la consecución de la justicia.

Por otra parte, la contrastabilidad de las prácticas impunes y violatorias a los derechos humanos, se centrarán en analizarlas a la luz del Tribunal Interamericano. Sin embargo, es imperioso destacar que la jurisprudencia de la Corte Interamericana, se ha caracterizado por su falta de concreción. La formulación de la mayoría de las obligaciones positivas en la jurisprudencia interamericana es etérea. Por ello, los

Facultad de Derecho y Ciencias Sociales - Universidad de Valparaíso - Chile 
Estados no suelen contar con indicadores concretos para poder determinar si están cumpliendo o no con las obligaciones positivas que se derivan de la Convención Americana ${ }^{1}$. A lo largo de este trabajo se van a identificar ocho líneas jurisprudenciales en materia de impunidad en la Corte Interamericana de Derechos Humanos, mediante el método de análisis de casos.

Una sociedad en la que priva la impunidad, se niega a reconocer lo que verdaderamente sucede, a la vez que se establece una contradicción fáctica entre cultura de legalidad y las garantías en un Estado de Derecho². Para engarzar la legalidad con la "cultura de legalidad", Wences y Sauca nos proponen tres escenarios: el primer escenario es el relativo al entramado institucional configurado en torno a la existencia de normas formales dotadas de notas de generalidad y abstracción. Aquí se abrigan tres principios: por un lado, el Estado de Derecho; por el otro, el imperio de la ley; y, por último, el principio de legalidad. El segundo escenario consiste en las luchas contra las transgresiones de la ley, representadas en las diferentes estrategias que deben ejercerse contra flagelos tales como las redes organizadas de delincuencia; el encubrimiento y blanqueo de capitales; los sobornos y un largo etcétera. Finalmente, el tercer escenario pone el acento en el desarrollo de nuevas formas de producción normativa que, por un lado, abren puertas a la proliferación de novedosas fórmulas de densidad normativa, como la pluralidad de instrumentos que se agrupan bajo la idea del soft law o estándares orientativos de aplicación normativa; y que, por otro, abren perspectivas a representaciones propias del pluralismo jurídico ${ }^{3}$. En esta

1. MONTOYA, Nicolás: "Indicadores cuantitativos del cumplimiento de las obligaciones positivas derivadas de la Convención Americana sobre Derechos Humanos”. En: Laurence Burgorgue-Larsen, Antonio Maués y Beatriz Sánchez Mojica, coords.: Manual de Derechos Humanos y Políticas Públicas. Red de Derechos Humanos y Educación Superior, Bogotá, 2014. P. 134.

2. WENCES, Isabel y SAUCA, José María: "Cultura de la legalidad: proyecto y movimiento”. En: Isabel Wences, José María Sauca y Adrián Bonilla editores. Cultura de la legalidad en Iberoamérica: desafíos y experiencias. Facultad Latinoamericana de Ciencias Sociales, 2014. P. 18.

3. Ibíd, pp. 31-34.

Revista de Ciencias Sociales - Número 71 (2017) - Universidad de Valparáíso - ISSN 0716-7725-Valparaíso, Chile 
proliferación de normas receptoras y preceptivas, es que puede ubicarse el derecho internacional de los derechos humanos y la producción de los diferentes tratados multilaterales en esta materia. El estudio de la jurisprudencia interamericana a realizar en esta ocasión, nos mostrará la senda a transitar por parte de los Estados suscriptores de la Convención Americana de Derechos Humanos, con la finalidad de no generar prácticas de impunidad.

\section{La Jurisprudencia de la Corte Interamericana de Derechos Humanos en la materia de estudio}

Una vez llegados a este punto, corresponde enfatizar algunos hitos jurisprudenciales que se derivan de los fallos de la Corte Interamericana de Derechos Humanos. Para centrarnos en esta labor, vamos a abordar diferentes tópicos desde una perspectiva deductiva - yendo de lo general hasta lo más específico-, a lo largo de ocho líneas jurisprudenciales que hemos encontrado bien definidas en este estudio.

Es así como se abordará en las líneas siguientes, las generalidades de lo que se entiende para el Alto Tribunal como impunidad; los deberes de los poderes públicos en esta materia; la simulación que puede suponer la denominada "cosa juzgada fraudulenta" para el combate en contra de no dejar hechos impunes; así como los alcances que deben realizarse sustentados en la obligación de investigar y llegar a determinar a los autores intelectuales; a los terceros que han actuado con la venia del Estado; lo inapropiado de utilizar mecanismos institucionales que fomenten la impunidad (amnistía, prescripción); así como el derecho que tienen los familiares a que las violaciones de derechos humanos de conocer lo que realmente sucedió, entre otras variables a esbozar. Procedemos sin más preámbulo a detallar los hallazgos obtenidos en esta investigación jurisprudencial.

\section{Definición y consistencia de la Impunidad en la jurisprudencia de la Corte Interamericana de Derechos Humanos}

Una primera definición de lo que la Corte Interamericana entiende como "impunidad", la podemos visualizar en la sentencia del Caso de la «Panel Blanca», en el que se concluye lo siguiente:

Facultad de Derecho y Ciencias Sociales - Universidad de Valparaíso - Chile 
"Deberes y obligaciones de los Estados para combatir la impunidad a la luz...

"La Corte constata que en Guatemala existió y existe un estado de impunidad respecto de los hechos del presente caso entendiéndose como impunidad la falta en su conjunto de investigación, persecución, captura, enjuiciamiento y condena de los responsables de las violaciones de los derechos protegidos por la Convención Americana, toda vez que el Estado tiene la obligación de combatir tal situación por todos los medios legales disponibles ya que la impunidad propicia la repetición crónica de las violaciones de derechos humanos y la total indefensión de las víctimas y de sus familiares”.

Asimismo y siempre dentro de la situación política imperante en el citado país centroamericano, la Corte constató que para el Caso Bámaca Velásquez, referido a la desaparición de un exguerrillero, existió y existe un estado de impunidad respecto de los hechos sucedidos, toda vez que pese a la obligación del Estado de prevenir e investigar, éste no lo hizo 5 .

En otro orden de cosas, en la sentencia de reparaciones dictada en noviembre del 2002, para el Caso Las Palmeras, la misma Corte Interamericana establece que casi un año antes —en sentencia del 6 de diciembre de 2001—, se resolvió que Colombia violó los artículos 8.1 y 25.1 de la Convención en perjuicio de los familiares de las personas

4. Corte IDH. Caso de la "Panel Blanca" (Paniagua Morales y otros) Vs. Guatemala. Fondo y reparaciones. Sentencia del 8 de marzo de 1998, Serie C 37, párr. 173. Cfr: Esta definición, se ha replicado al menos en los siguientes casos: Corte IDH, Caso Juan Humberto Sánchez Vs. Honduras. Excepción Preliminar, Fondo, Reparaciones y Costas. Sentencia de 7 de junio de 2003, Serie C 99, párr. 143 y 185; Corte IDH. Caso de los Hermanos Gómez Paquiyauri Vs. Perú. Fondo, Reparaciones y Costas. Sentencia de 8 de julio de 2004, Serie C 204, párr. 148 y Corte IDH. Caso Huilca Tecse Vs. Perú. Fondo, Reparaciones y Costas. Sentencia de 3 de marzo de 2005. Serie C No 121, párr. 82.

5. Corte IDH. Caso Bámaca Velásquez Vs. Guatemala. Fondo. Sentencia de 25 de noviembre de 2000. Serie C No 70, párr. 211. Cfr: Corte IDH. Caso de los "Niños de la Calle" (Villagrán Morales y otros vs. Guatemala). Reparaciones (Art. 63.1 de la Convención Americana sobre Derechos Humanos). Sentencia de 26 mayo de 2001. Serie C No 77, párr. 100.

Revista de Ciencias Sociales - Número 71 (2017) - Universidad de Valparáíso - ISSN 0716-7725-Valparaíso, Chile 
indicadas en su resolutivo número cuatro. Se ha entendido que la "situación de impunidad", debe ser entendida de la siguiente manera, según el párrafo 53, punto a), de la siguiente manera:

“a) Por una parte, se hallan todos los daños ocasionados por la deficiente conducción de los procesos judiciales, su morosidad y las obstaculizaciones llevadas a cabo para impedir que se llegue a una decisión pronta y adecuada. En este sentido, cabe recordar lo que expone la sentencia referida al procedimiento disciplinario $\mathrm{y}$ al proceso penal ordinario. A esto hay que agregar que algunos miembros de la policía alteraron, ocultaron y destruyeron pruebas. Todo esto condujo a la Corte a decir que existía una "situación de impunidad". El daño ocasionado por esta situación consiste en la imposibilidad de que los verdaderos responsables sean sancionados, todo lo cual crea en los familiares de las víctimas una sensación de indefensión y angustia”.

La Corte Interamericana desde Caso Velásquez Rodríguez contra Honduras, vinculó el principio derivado del artículo segundo de la Convención Americana de Derechos Humanos, referente a la obligación que tienen los Estados de adoptar medidas internas para salvaguardar y garantizar los derechos del instrumento interamericano. De igual manera, adujo que:

"El Estado está en el deber jurídico de prevenir, razonablemente, las violaciones de los derechos humanos, de investigar seriamente con los medios a su alcance las violaciones que se hayan cometido dentro del ámbito de su jurisdicción a fin de identificar a los responsables, de imponerles las sanciones pertinentes y de asegurar a la víctima una adecuada reparación”"

6. Corte IDH. Caso Las Palmeras Vs. Colombia. Reparaciones y Costas. Sentencia de 26 noviembre de 2002. Serie C No 96, párr. 53 a).

7. Corte IDH. Caso Velásquez Rodríguez Vs. Honduras. Fondo. Sentencia del 29 de julio de 1988, Serie C 04, párr. 174.

Facultad de Derecho y Ciencias Sociales - Universidad de Valparaíso - Chile 
El antecedente citado, se constituye en la primera mención que realiza la Corte Interamericana, con respecto a la necesidad impuesta que tienen los Estados de investigar. Posteriormente, en el Caso Loayza Tamayo contra Perú, se vincula el artículo segundo de la Convención Americana de Derechos Humanos, con la obligación que tiene el Estado de "investigar los hechos del presente caso, identificar a sus responsables y sancionarlos y adoptar las disposiciones de derecho interno que sean necesarias para asegurar el cumplimiento de esta obligación"8. Este antecedente igualmente es reiterado para el proceso contencioso denominado Suárez Rosero ${ }^{9}$, y no es sino hasta con el Caso Blake, que el Alto Tribunal Interamericano aduce que el derecho interno debe volcarse a adoptar el cumplimiento de la obligación de vencer esta impunidad ${ }^{10}$.

El Tribunal ha señalado que el Estado tiene el deber de evitar y combatir la impunidad, siendo que ésta última la ha definido como "la falta en su conjunto de investigación, persecución, captura, enjuiciamiento y condena de los responsables de las violaciones de los derechos protegidos por la Convención Americana"11.

En síntesis, las anteriores definiciones son preponderantemente más de índole operativas y no tanto definitorias del concepto de impunidad. En el fondo, esta tendencia es acorde con una visión más pragmática de lo que implica el flagelo de la impunidad en la práctica: ausencia total de una serie de necesidades para que el sistema de justicia

8. Corte IDH. Caso Loayza Tamayo Vs. Perú, párr. 171.

9. Corte IDH. Caso Suárez Rosero Vs. Ecuador. Reparaciones y Costas. Sentencia de 20 de enero de 1999, Serie C No 51, párr. 80.

10. Corte IDH. Caso Blake Vs. Guatemala. Reparaciones y Costas. Sentencia de 22 de enero de 1999, Serie C No 48, párr. 65. Cfr: Este antecedente es reiterado en Corte IDH. Caso del Tribunal Constitucional Vs. Perú. Fondo, Reparaciones y Costas. Sentencia de 31 de enero de 2001. Serie C No 71, párr. 123; Corte IDH. Caso Ivcher Bronstein Vs. Perú. Fondo, Reparaciones y Costas. Sentencia de 6 de febrero de 2001. Serie C No 74, párr. 186.

11. Corte IDH. Caso Maritza Urrutia Vs. Guatemala. Fondo, Reparaciones y Costas. Sentencia de 27 de noviembre de 2003. Serie C No 103, párr.126. Cfr: Corte IDH. Caso Bulacio Vs. Argentina. Fondo, reparaciones y costas. Sentencia de 18 de septiembre de 2003. Serie C No 100, párr. 120; y Corte IDH. Caso Juan Humberto Sánchez Vs. Honduras, párr. 143. 
funcione eficazmente. Es así que para el Alto Tribunal Interamericano, el fenómeno en estudio se reduce a una disfuncionalidad del sistema judicial, por su permisividad u omisión, siendo que esta actitud dificulta la rendición de cuentas a los familiares y a la comunidad nacional en general.

Estamos ante una violación masiva y sistemática de los derechos humanos, que impide identificar causas y culpables, no siendo posible aplicar colateralmente, el remedio jurisdiccional como mecanismo de control social de la pena. Si no existen indicios de los culpables; el Estado de Derecho genera sendos vacíos a la credibilidad ciudadana.

\section{Deber del Estado de evitar y combatir la impunidad}

Como un antecedente previo, nos vamos a encontrar que la Corte Interamericana de Derechos Humanos, ha advertido en el Caso Urrutia, que "[...] el Estado tiene la obligación de combatir tal situación por todos los medios legales disponibles ya que la impunidad propicia la repetición crónica de las violaciones de derechos humanos y la total indefensión de las víctimas y de sus familiares”12.

12. Cfr. Caso Maritza Urrutia. Op Cit, párr. 267. Un año después, se vuelve a invocar este antecedente en Corte IDH. Caso 19 Comerciantes Vs. Colombia. Fondo, Reparaciones y Costas. Sentencia de 5 de julio de 2004. Serie C No 109, párr. 175. El antecedente es reiterado en el Caso Penal Miguel Castro Castro Vs Perú, y al respecto la Corte Interamericana aduce lo siguiente: "[Obligación estatal de combatir la impunidad por todos los medios legales disponibles, Naturaleza, de hechos en contexto de violación sistemática de derechos genera mayor necesidad de erradicar la impunidad, Obligación estatal de combatir la impunidad tomando en cuenta la necesidad de hacer justicia] Este Tribunal ha señalado invariablemente que el Estado tiene el deber de evitary combatir la impunidad, caracterizada como "la falta en su conjunto de investigación, persecución, captura, enjuiciamiento y condena de los responsables de las violaciones de los derechos protegidos por la Convención Americana". Se debe combatir la impunidad por todos los medios legales disponibles, tomando en cuenta la necesidad de hacer justicia en el caso concreto y que aquélla propicia la repetición crónica de las violaciones de derechos humanos y la total indefensión de las víctimas". Corte IDH. Caso del Penal Miguel Castro Castro Vs. Perú. Fondo, Reparaciones y Costas. Sentencia de 25 de noviembre de 2006. Serie C No 160, párr. 405. Cfr: Corte IDH. Caso Vargas Areco Vs. Paraguay. Sentencia de 26 de septiembre de 2006. Serie C No 155 , párr. 153.

Facultad de Derecho y Ciencias Sociales - Universidad de Valparaíso - Chile 
Lo que suscita con la anterior jurisprudencia, no es ni más ni menos, que la necesidad de promover una "cultura de la legalidad" como "cultura jurídica". La primera acepción alude a ideas y valores de una colectividad, pero una cosa es la cultura jurídica preponderante en una comunidad (ese conjunto de saberes diseñado por los juristas y los académicos) y otra distinta sería, la cultura de la legalidad de los miembros de dicha colectividad, que se refiere "a la relación que existe entre la generalidad de los destinatarios de las normas y el ordenamiento jurídico vigente en su colectividad"13. Esta cultura de legalidad en el sentido jurídico, debe de ir evolucionando hacia mecanismos de tutela y resguardo, establecidos y diseñados para evitar como fin inmediato, el acrecimiento de la impunidad. Al hablarse de $<<$ todos los medios legales disponibles $>>$, supone desde nuestra perspectiva a visualizar a los mecanismos dispuestos para combatir la impunidad, desde una dimensión horizontal y vertical; en su carácter de extensión y competencia funcional del Derecho. Es decir, los medios legales deben ser variados y efectivos para defender las garantías constitucionales y de los derechos humanos, - p.e. recursos de amparo, hábeas corpus, justicia administrativa etc.- y de igual manera, deben ser susceptibles de ser revisados por jerarquía, con la finalidad de controlar lo actuado por el inferior por parte del superior.

Por otra parte, el Alto Tribunal interamericano, se ha manifestado en destacar que la naturaleza y gravedad de los hechos en contextos de violaciones sistemáticas de derechos humanos, genera una mayor necesidad de erradicar la impunidad de los hechos ${ }^{14}$. Estas violaciones si se quiere estructurales, tienen los siguientes indicadores negativos que inciden en el umbral de la impunidad absoluta: 1. Afectan a un gran número de personas que por sí mismas o mediante organizaciones que las representan en juicio alegan violaciones de sus derechos; 2. Involucran varios órganos públicos, responsables de las fallas persistentes de la política pública que contribuyen a esas violaciones de derechos, y que; 3. Implican requerimientos judiciales de carácter estructural, es

13. WENCES, Isabel y SAUCA, José María, ob. cit., p. 38.

14. Corte IDH. Caso Goiburú y otros Vs. Paraguay. Fondo, Reparaciones y Costas. Sentencia de 22 de septiembre de 2006. Serie C No 153, párr. 131.

Revista de Ciencias Sociales - Número 71 (2017) - Universidad de Valparáíso - ISSN 0716-7725-Valparáiso, Chile 
decir, órdenes de cumplimiento obligatorio por las cuales los tribunales instruyen a esos organismos públicos para que actúen de forma coordinada a fin de proteger a toda la población afectada y no sólo a los demandantes específicos del caso ${ }^{15}$.

Se impone entonces, generar una reflexión profunda en torno a cuáles son las vías que posee el Estado de Derecho Moderno para combatir el anterior flagelo y la respuesta, no es del todo fácil. Para un autor como Ferrajoli, el garantismo sería una posibilidad de replantear el paradigma de la función pública: consiste en la incorporación de vínculos sustanciales, no importa que consistan en deberes positivos (de hacer) en vez de negativos (de no hacer), a las decisiones de los poderes públicos ${ }^{16}$. En nuestro medio, Rivero Sánchez, nos aduce sobre el modelo garantista lo siguiente:

"En su carácter mediador entre la norma jurídica y su contexto social, el modelo garantista constituye una forma de reflexión del derecho constitucional que sólo considera justo o correcto aquel sistema jurídico que garantice respeto a la autonomía ética del ser humano, que limite la intervención de las instancias oficiales de control de la forma más precisa posible, que permita determinar racionalmente cuales son los bienes jurídicos que serán dignos de tutela y que, en general, dé garantía de seguridad jurídica y de eliminación de la arbitrariedad.

El surgimiento del modelo constitucional clásico garantista (como forma de reflexión del derecho constitucional que permite la diferenciación entre el derecho y la moral), contribuye al desarrollo de la autopoiesis tanto del sistema jurídico como del moral y hace patente la necesidad de desarrollar mecanismos de ajuste estructural entre ambos, con lo que impulsa, a su vez, el desarrollo de los derechos fundamentales y el establecimiento del orden constitucional" ${ }^{17}$.

15. RODRÍGUEZ, César y RODRÍGUEZ, Diana: Juicio a la exclusión: El impacto de los tribunales sobre los derechos sociales en el Sur Global. Colección derecho y política, Siglo veintiuno editores S.A.-Dejusticia, Buenos Aires, 2015. P. 25.

16. FERRAJOLI, Luigi: Derechos y garantías: La ley del más débil. Séptima edición Editorial Trotta, Madrid, 2010. P. 30.

17. RIVERO, Juan Marcos: Constitución, Derechos Fundamentales y Derecho Privado. Biblioteca Jurídica Diké, Ediciones Areté, San José, Costa Rica, 2001. Pp. 118-119.

Facultad de Derecho y Ciencias Sociales - Universidad de Valparaíso - Chile 
La apuesta por una postura garantista, se presenta como la respuesta institucional fuerte que el sistema político necesita, para hacer prevalecer el Estado de Derecho. Sin embargo, debe tenerse en cuenta que la lucha contra la impunidad tiene grandes objetivos, que se presentan como valores a realizar y que se encarnan en la realidad de manera casi siempre imperfecta, a los que no puede resistirse la gobernanza estatal: (i) El conocimiento de la verdad, el cumplimiento del deber de memoria y la preservación de pruebas; (ii) La realización de la justicia y, (iii) La reparación, que incluye las garantía de no renovación ${ }^{18}$.

Esta posición garantista atribuida al quehacer de las potestades y órganos públicos, se refleja en la misma jurisprudencia de la Corte Interamericana, cuando en el caso "La Masacre de Santo Domingo vs. Colombia”, dictaminó que:

"el Estado "es el principal garante de los derechos humanos de la personas, de manera que, si se produce un acto violatorio de dichos derechos, es el propio Estado quien tiene el deber de resolver el asunto a nivel interno y, [en su caso,] reparar, antes de tener que responder ante instancias internacionales como el Sistema Interamericano, lo cual deriva del carácter subsidiario que reviste el proceso internacional frente a los sistemas nacionales de garantías de los derechos humanos". Esas ideas también han adquirido forma en la jurisprudencia reciente bajo la concepción de que todas las autoridades y órganos de un Estado Parte en la Convención tienen la obligación de ejercer un "control de convencionalidad" 19 .

18. MATTAROLLO, Rodolfo: "Las comisiones de la verdad en Instituto Interamericano de Derechos Humanos. Verdad y Justicia”. En: Homenaje a Emilio F. Mignone, IIDH, San José. 2001. P. 156.

19. Corte IDH. Caso Masacre de Santo Domingo Vs. Colombia. Excepciones Preliminares, Fondo y Reparaciones. Sentencia de 30 de noviembre de 2012. Serie C No 259, párr. 142. Cfr: En torno al denominado "control de convencionalidad", esta práctica judicial presenta dos manifestaciones en el marco del sistema interamericano de protección de los derechos humanos y la aplicación de la Convención Americana de Derechos Humanos: una de carácter concentrado que ejerce únicamente 
En síntesis, para combatir la impunidad se espera que el ente estatal se mueva en una dirección contraria, a la que normalmente realiza. Las garantías deben provenir de la respuesta judicial y del aparato político en sentido lato, siendo reforzadas por la necesidad de aplicar en sede interna, todo el elenco de disposiciones emanadas de la Corte Interamericana - tales como las que analizamos en este ensayo-, tendientes a elevar el estándar de derechos a tutela, siguiendo la aplicación convencional dentro del sistema jurídico endógeno en su conjunto.

\section{La "cosa juzgada fraudulenta" y sus implicaciones en la Impunidad y conocimiento verdadero de los hechos}

Es importante acotar que la jurisprudencia interamericana ha venido delineando a partir del año 2000 en una serie de fallos, los alcances con respecto a lo que debe entenderse como "cosa juzgada fraudulenta" ${ }^{20}$. Tenemos inicialmente que en el caso Carpio Nicolle y otros contra el Estado de Guatemala, la Corte Interamericana adujo que la normativa internacional viene examinando a que se conoce como este tipo de fraude — art. 20 del Estatuto de Roma de la Corte Penal Internacional (1998); art. 20; Estatuto del Tribunal Internacional para

la Corte Interamericana de Derechos Humanos y otra de carácter difuso que ejercen los jueces a nivel nacional, aprovechándose de las provisiones y resoluciones de la Corte Interamericana. Para ahondar sobre el tema, véase a MIRANDA, Haideer: Derechos fundamentales en América Latina. Serie Integración Regional y Derecho Comunitario, Editorial Jurídica Continental, San José, 2015. Pp. 105-163. En el fondo, estamos hablando ni más ni menos de la posibilidad que tiene la jurisdicción ordinaria o del fuero interno de los Estados suscriptores de la CADH, para aplicar los precedentes de la jurisprudencia de la Corte Interamericana de Derechos Humanos. En este marco, la Convención pasa a constituirse en un parámetro de observancia superior a la normativa doméstica o propia.

20. Véase al respecto, el artículo de CHACÓN, Alfonso: "La cosa Juzgada Fraudulenta en la jurisprudencia de la Corte Interamericana de Derechos Humanos: Implicaciones para el Estado de Derecho Contemporáneo”. En: Revista Prolegómenos, Derechos y Valores, Centro de Investigaciones de la Facultad de Derecho de la Universidad Militar de Nueva Granada, Volumen XVIII No 35, 2015.

Facultad de Derecho y Ciencias Sociales - Universidad de Valparaíso - Chile 
Ruanda (1994) y el art. 9 del Estatuto del Tribunal Internacional para la ex Yugoslavia (1993) — y ha externado que esta actividad defectuosa resulta, de un juicio en el que no se han respetado las reglas del debido proceso, o cuando los jueces no obraron con independencia e imparcialidad $^{21}$. Se propicia con esta resolución, un verdadero diálogo entre Cortes disímiles, al invocarse antecedentes en otro foro de juzgamiento del derecho internacional de los derechos humanos y por ende, la construcción del pórtico de protección con otros antecedentes, complementa la jurisdicción interamericana.

La otra referencia que vertió la jurisprudencia interamericana en materia de cosa juzgada fraudulenta, lo tenemos en el Caso Almonacid Arellano y otros contra Chile, que tiene el mérito de aplicar en las consideraciones de su sentencia, los alcances establecidos previamente para reconocer cuando se está en presencia de un acto jurisdiccional viciado de esta práctica. Se pronuncia con respecto a que el principio de Non Bis in Ídem, aún cuando constituye garantía de un derecho humano reconocido en el artículo 8.4 de la Convención Americana, no es un derecho absoluto y, por tanto, no resulta aplicable cuando: i) la actuación del tribunal que conoció el caso y decidió sobreseer o absolver al responsable de una violación a los derechos humanos o al derecho internacional obedeció al propósito de sustraer al acusado de su responsabilidad penal; ii) el procedimiento no fue instruido independiente o imparcialmente de conformidad con las debidas garantías procesales, o iii) no hubo la intención real de someter al responsable a la acción de la justicia ${ }^{22}$. Se logra determinar en este caso la aplicación fraudulenta de la justicia, al cumplirse dos de los supuestos señalados. En primer lugar, la causa fue llevada por tribunales que no guardaban la garantía de competencia, independencia e imparcialidad. En segundo lugar, la aplicación del Decreto Ley No 2.191 consistió en

21. Corte IDH. Caso Carpio Nicolle y otros Vs. Guatemala. Fondo, Reparaciones y Costas. Sentencia de 22 de noviembre 2004. Serie C N ${ }^{\circ} 117$, párr. 131.

22. Corte IDH. Caso Almonacid Arellano y otros Vs. Chile. Excepciones Preliminares, Fondo, Reparaciones y Costas. Sentencia de 26 de septiembre de 2006. Serie C No 154, párr. 153. 
sustraer a los presuntos responsables de la acción de la justicia y dejar el crimen cometido en contra del señor Almonacid Arellano en la Impunidad $^{23}$.

Sin duda alguna, un aporte jurisprudencial del citado caso, al combate contra la impunidad y el correlativo deber de derecho a la verdad; parte de la consideración de poner en evidencia, cuando estamos en presencia de una "justicia imaginada". Aquellos fallos en los que deliberadamente, se prescinda de las garantías esenciales del debido proceso, se tornan en insolutos; es un crédito no pagado o rendido correctamente en las vías jurisdiccionales. La "cosa juzgada fraudulenta”, es sin duda alguna, el déficit más severo para cualquier sistema político que se pretenda catalogarse de democrático, y para los efectos de este trabajo, constituye una negación rotunda al ideal de justicia.

La fraudulencia llevada a cabo en un cuasi-proceso jurisdiccional, se constituye en una burla absoluta para el Estado de Derecho, y sobre todo; es una manera inapropiada de encubrir las realidades de sendos casos de corrupción o violación de los derechos humanos. Es obvio que bajo este resquicio ornamental de "justicia degradada", la impunidad florece a todas sus anchas, y por consiguiente, la Corte Interamericana no duda en catalogar estas prácticas juzgatorias como violatorias al mismo espíritu de la Convención Americana de Derechos Humanos.

De igual manera, la jurisprudencia interamericana en el Caso Gutiérrez y Familia, se ha referido a las obstrucciones en el proceso, como una práctica que es contraria al debido proceso, ya que se pretende que se faciliten todos los medios necesarios para proteger a los operadores de justicia, investigadores, testigos y familiares de las víctimas de hostigamientos y amenazas que tengan como finalidad entorpecer el proceso y evitar el esclarecimiento de los hechos y encubrir a los responsables de los mismos ${ }^{24}$. En este asunto, se cuestiona la fraudulencia de la investigación llevada a cabo por el Estado argentino, todo ello que se obviaron las garantías elementales.

23. Corte IDH. Caso Almonacid Arellano y otros Vs. Chile, párr. 155.

24. Corte IDH. Caso Gutiérrez y Familia Vs. Argentina. Fondo, Reparaciones y Costas. Sentencia del 25 de noviembre de 2013. Serie C No 271, párr. 118.

Facultad de Derecho y Ciencias Sociales - Universidad de Valparaíso - Chile 


\section{Obligación estatal de sancionar a los responsables de una violación de derechos cumpliendo el deber de investigar}

Para empezar este lineamiento jurisprudencial, se hace imperioso destacar que los responsables violaciones a los derechos humanos en sentido general, deben responder por las faltas incurridas. Con mucha mayor razón todavía, si tenemos entre éstos a funcionarios del Estado que actúan en nombre y bajo la aquiescencia del mismo poder político. El Estado actúa por medio de sus funcionarios — llamados agentes en el Derecho Internacional-, quienes comprometen con su acción u omisión al ente estatal, "debido a que la actividad del Estado siempre implica un riesgo de provocar algún daño o perjuicio a la esfera de los derechos de las personas, sin que necesariamente impliquen la comisión de un delito. Ello se conoce como "responsabilidad objetiva" del Estado, lo que quiere decir que el Estado debe saber "elegir" y "vigilar" a sus funcionarios" 25 .

La jurisprudencia de la Corte Interamericana, ha asociado que la obligación de respetar los derechos de la Convención Americana de Derechos Humanos, con el correlativo deber de adoptar tales disposiciones en el foro interno - consagrados en el artículo 1.1 y 2 del instrumento internacional—-, se extiende igualmente a la obligación estatal de investigar, identificar y sancionar a los responsables de las violaciones de derechos humanos. En este otro descriptor, vamos a caracterizar esta obligación estatal en sentido genérico, puesto que en los desenlaces jurisprudenciales siguientes, vamos a detallar en dos categorías fácticas de la ausencia de castigo: nos referimos a los autores intelectuales y a los ejecutores perpetuadores de la falta. La finalidad de la responsabilidad amplia del poder punitivo, consiste en que todas las personas que intervienen en este tipo de trama tan siniestra sean sancionados, por lo que quienes tienen responsabilidad directa en la práctica, no deben quedar impunes.

Concretamente, en el caso Loayza Tamayo se establece que las anteriores obligaciones, se deben adoptar en el marco del derecho

25. RODRÍGUEZ, Víctor: Curso de Derechos Humanos. Investigaciones Jurídicas S.A., San José, 2016. P. 33.

Revista de Ciencias Sociales - Número 71 (2017) - Universidad de Valparáíso - ISSN 0716-7725-Valparaíso, Chile 
interno, para asegurar lo dispuesto en el artículo 2 de la Convención Americana ${ }^{26}$. Es decir, los Estados deben realizar todos los esfuerzos posibles para sancionar eficazmente a los responsables por violaciones a los derechos humanos, y para lograr este acometido no deben tener sistemas procesales diseñados para la prevalencia de la impunidad y la obstaculización de la verdad.

De nuestra parte, nos parece revelador el Caso de la "Masacre de Mapiripán" contra Colombia, en el que se hace una concatenación entre las potestades del Estado, el conocimiento de los hechos que sustentan violaciones a los derechos humanos, y como deben iniciar ex officio y sin dilación una investigación seria, imparcial y efectiva. Esta investigación debe ser realizada por todos los medios legales disponibles, y ser orientada a la determinación de la verdad. La obligación del Estado de investigar debe cumplirse diligentemente para evitar la impunidad y que este tipo de hechos vuelvan a repetirse ${ }^{27}$.

En otras palabras, la responsabilidad sancionatoria tiene su asidero principal, en la efectividad que pueda ostentar un determinado sistema de procesamiento punitivo, que lleve hasta las últimas consecuencias las graves violaciones a los derechos humanos. En consecuencia, la investigación debe ser asumida por el Estado como un deber jurídico propio y no como una simple formalidad condenada de antemano a ser infructuosa, o como una mera gestión de intereses particu-

26. Corte IDH, Caso Loayza Tamayo Vs. Perú, párr. 171. En otra sentencia se analiza el artículo segundo de la Convención Americana, en cuanto a la obligación de adoptar las medidas necesarias para hacer efectivos los derechos establecidos dentro de la convención, indicando lo siguiente: "El deber general del artículo 2do de la Convención Americana de Derechos Humanos implica la adopción de medidas en dos vertientes. Por una parte la supresión de las normas y prácticas de cualquier naturaleza que entrañen violación a las garantías previstas en la Convención. Por la otra, la expedición de normas y el desarrollo de prácticas conducentes a la efectiva observancia de dichas garantías" Corte IDH. Caso Castillo Petruzzi y otros Vs. Perú. Fondo, Reparaciones y Costas. Sentencia de 30 de mayo de 1999. Serie C No 52, párr. 207.

27. Corte IDH. Caso de la "Masacre de Mapiripán” Vs. Colombia. Fondo, Reparaciones y Costas. Sentencia de 15 de septiembre de 2005. Serie C No 134 , párr. 219, 222 y 223.

Facultad de Derecho y Ciencias Sociales - Universidad de Valparaíso - Chile 
lares, que dependa de la iniciativa procesal de las víctimas o de sus familiares o de la aportación privada de elementos probatorios ${ }^{28}$.

Finalmente, para que la investigación se considere efectiva debe cumplir con los estándares internacionales en la materia, por lo que la Corte IDH ha considerado que las investigaciones "deben tomar en consideración las normas internacionales de documentación e interpretación de los elementos de prueba forense respecto de la comisión de actos de tortura y, particularmente, las definidas en el Protocolo de Estambul" (Caso Vargas Areco v. Paraguay, fondo, reparaciones y costas, párrafo 93 $)^{29}$.

\section{Obligación estatal de identificar y sancionar a los autores intelectuales de violaciones de derechos humanos}

Entramos a analizar otra línea jurisprudencial dispuesta por el Tribunal Interamericano y se encausa a la identificación de quienes idean y planifican intelectualmente, las violaciones de los derechos humanos individuales o colectivos, y que no pueden ser perfectamente los perpetradores de la violación desde un plano fáctico. Desde sus primeras resoluciones, la Corte establece en el Caso Velásquez Rodríguez, una serie de pautas esperadas de los entes públicos, tratándose de la vigencia de los derechos humanos, siendo que desde su óptica, "El Estado está en el deber jurídico de prevenir, razonablemente, las violaciones de los derechos humanos, de investigar seriamente con los medios a su alcance las violaciones que se hayan cometido dentro del ámbito de su jurisdicción a fin de identificar a los responsables, de imponerles las sanciones pertinentes y de asegurar a la víctima una adecuada reparación" ${ }^{30}$.

28. Corte IDH, Caso Velásquez Rodríguez Vs Honduras. Fondo, párr. 177.

29. FERRER, Eduardo: "Las siete principales líneas jurisprudenciales de la Corte Interamericana de Derechos Humanos aplicable a la justicia penal”. En: Revista Instituto Interamericano de Derechos Humanos (IIDH), Edición especial en homenaje a Elizabeth Odio Benito, San José: Costa Rica, 2014. P. 39.

30. Corte IDH, Caso Velásquez Rodríguez Vs Honduras, Fondo, párr. 174.

Revista de Ciencias Sociales - Número 71 (2017) - Universidad de Valparáíso - ISSN 0716-7725-Valparáíso, Chile 
Siguiendo en este caso, la misma Corte Interamericana manifestó que la obligación de dar con los responsables se mantiene "cualquiera sea el agente al cual pueda eventualmente atribuirse la violación, aún los particulares, pues, si sus hechos no son investigados con seriedad, resultarían, en cierto modo, auxiliados por el poder público, lo que comprometería la responsabilidad internacional del Estado" ${ }^{11}$.

Posteriormente, la anterior garantía genérica, se clarifica con los alcances dados por el Caso Loayza Tamayo, referentes al deber estatal de identificar a quienes han diseñado los operativos y acciones, tendientes a las violaciones sistemáticas de los derechos humanos. Al respecto, enunció en su momento que:

"La Convención Americana garantiza que toda persona sujeta a la jurisdicción de un Estado tiene la posibilidad de acudir ante la justicia para hacer valer sus derechos y asimismo impone a los Estados la obligación de prevenir, investigar, identificar y sancionar a los autores intelectuales y encubridores de violaciones de los derechos humanos. Los Estados no pueden, para no dar cumplimiento a sus obligaciones internacionales, invocar disposiciones existentes en su derecho interno, como lo es en este caso la Ley de Amnistía expedida por el Perú, que a juicio de esta Corte, obstaculiza la investigación y el acceso a la justicia. Por estas razones, el argumento del Perú en el sentido de que le es imposible cumplir con ese deber de investigar los hechos que dieron origen al presente caso debe ser rechazado" ${ }^{2}$.

Un año después, el Alto Tribunal cuando falla el Caso Blake, vuelve a ser reiterativo en esta obligación ${ }^{33}$ y recalca en la necesidad de identificar a los autores intelectuales de los flagelos perpetuados. Sin embargo, estimamos que los veredictos establecidos en los contenciosos

\footnotetext{
31. Corte IDH, Caso Velásquez Rodríguez Vs Honduras, Fondo, párr. 177.

32. Corte IDH. Caso Loayza Tamayo Vs. Perú, párr. 168.

33. Corte IDH. Caso Blake Vs. Guatemala, párr. 61.
}

Facultad de Derecho y Ciencias Sociales - Universidad de Valparaíso - Chile 
Caso Masacres de El Mozote y lugares aledaños (2012) y el Caso Osorio Rivera y Familiares (2013), sientan una serie de pautas más concretas, en relación al deber de identificar y sancionar como efecto posterior, a los responsables de las violaciones a los derechos humanos de terceros.

En el primer asunto, establece que el Estado salvadoreño debe investigar de forma efectiva todos los hechos de las masacres, aunque hayan transcurrido treinta años de los hechos, incluyendo, además de las ejecuciones extrajudiciales, otras posibles graves afectaciones a la integridad personal, y en particular, los actos de tortura y las violaciones sexuales contra las mujeres, así como los desplazamientos forzados. A tal fin, el Estado debe realizar una serie de obligaciones positivas o de acción inmediata, entre las que rescatamos las siguientes, para efectos de este acápite:

"b) tomar en cuenta el patrón sistemático de violaciones a derechos humanos en el contexto del conflicto armado salvadoreño, así como los operativos militares de grandes proporciones dentro de los que se enmarcaron los hechos de este caso, con el objeto de que los procesos y las investigaciones pertinentes sean conducidos en consideración de la complejidad de estos hechos y el contexto en que ocurrieron, evitando omisiones en la recolección de prueba y en el seguimiento de líneas lógicas de investigación con base en una correcta valoración de los patrones sistemáticos que dieron origen a los hechos que se investigan; c) identificar e individualizar a todos los autores materiales e intelectuales de las masacres del presente caso. La debida diligencia en la investigación implica que todas las autoridades estatales están obligadas a colaborar en la recaudación de la prueba, por lo que deberán brindar al juez, fiscal u otra autoridad judicial toda la información que requiera y abstenerse de actos que impliquen la obstrucción para la marcha del proceso investigativo" ${ }^{34}$.

34. Corte IDH. Caso Masacres de El Mozote y lugares aledaños Vs. El Salvador, párr. 319.

Revista de Ciencias Sociales - Número 71 (2017) - Universidad de Valparáíso - ISSN 0716-7725-Valparaíso, Chile 
Nótese como se impone una investigación eficaz y certera, que detalle e individualice a los autores intelectuales — que no participan directamente en el caso-, así como a los autores materiales o fácticos, de la violación específica de los derechos humanos a terceros. En América Latina, se han podido instruir algunas causas en la jurisdicción interna, que sentenciaron a políticos y gobernantes orquestadores de manera activa o intelectual, en graves violaciones a los derechos humanos. El caso del expresidente Jorge Videla, durante gran parte de la dictadura en Argentina (1976-1984), y como la Sala I de la Cámara Nacional de Apelaciones en lo Criminal y Correccional Federal (21/ 08/2003), confirmó la decisión del juez de primera instancia en cuanto a la condena por sustracción y robo de niños. Otros siguen esperando juicio y se ha avanzado judicialmente en este sentido, a pesar de los amaños y retardos procesales que se ha provocado en la defensa, como sería la situación de las imputaciones de genocidio al Gral. Efraín Ríos Montt en Guatemala.

Ahora bien, en el segundo caso a reseñar, la Corte dispone que el Estado debe conducir eficazmente investigaciones y abrir procesos penales en relación con la desaparición forzada en perjuicio de Jeremías Osorio Rivera para determinar la responsabilidad de todos los autores materiales e intelectuales de los hechos y aplicar efectivamente las sanciones y consecuencias que la ley prevea. En ese sentido, la debida diligencia en la investigación implica que todas las autoridades estatales correspondientes están obligadas a colaborar en la recolección de la prueba, y en particular, el Estado debe con respecto a los autores intelectuales, adoptar las siguientes medidas:

- Identificar e individualizar a los autores materiales e intelectuales de la desaparición forzada de la víctima;

- Por tratarse de una violación grave de derechos humanos, y en consideración del carácter permanente o continuo de la desaparición forzada cuyos efectos no cesan mientras no se establezca el paradero de la víctima o se identifiquen sus restos, el Estado debe abstenerse de recurrir a figuras como la amnistía en beneficio de los autores, así como ninguna otra disposición análoga, la prescripción, irretroactividad de la ley penal, cosa

Facultad de Derecho y Ciencias Sociales - Universidad de Valparaíso - Chile 
"Deberes y obligaciones de los Estados para combatir la impunidad a la luz...

juzgada, ne bis in idem o cualquier eximente similar de responsabilidad, para excusarse de esta obligación ${ }^{35}$.

Correlativamente al deber de identificación de aquellas personas que planeen y diseñen las violaciones, la Corte Interamericana ha establecido la necesidad de sancionarlas. La debida diligencia en la investigación implica que todas las autoridades estatales están obligadas a colaborar en la recaudación de la prueba, por lo que deberán brindar al juez, fiscal u otra autoridad judicial toda la información que requiera y abstenerse de actos que impliquen la obstrucción para la marcha del proceso investigativo. En particular, el Caso Barrios Altos, ha establecido jurisprudencialmente que el Estado deberá realizar la o las investigaciones pertinentes en relación con los hechos del presente caso, con el objeto de que el proceso y las investigaciones sean conducidas en consideración de la complejidad de los hechos y contexto en que ocurrieron, evitando omisiones en la recolección de prueba y en el seguimiento de líneas lógicas de investigación; asegurarse que las autoridades competentes realicen las investigaciones correspondientes ex officio, y que para tal efecto tengan a su alcance y utilicen todos los recursos logísticos y científicos necesarios para recabar y procesar las pruebas $^{36}$.

En el fondo, lo que se persigue no basta con garantizar en la máxima medida posible que la justicia sea imparcial; es preciso, además, que sea eficaz: "Ello implica, al menos, tres cosas: en primer lugar, que sea accesible, es decir, que carezca de cualquier tipo de traba o barrera que impliquen discriminación en la obtención de una adecuada tutela y protección judicial. En segundo lugar, que proporcione solución razonablemente diligente a los conflictos que le son presentados. Y en tercer lugar que garantice la adecuada y puntual ejecución de sus sentencias" ${ }^{37}$.

35. Corte IDH. Caso Osorio Rivera y Familiares Vs. Perú. Excepciones Preliminares, Fondo, Reparaciones y Costas. Sentencia de 26 de noviembre de 2013. Serie C No 274, párr. 244.

36. Corte IDH. Caso Barrios Altos Vs. Perú. Fondo. Sentencia de 14 de marzo de 2001. Serie C No 75, párr. 41.

37. José Juan Toharia, “Cultura de legalidad y Buena Justicia”. En: Wences, Isabel y Sauca, José María, ob. cit., p. 14.

Revista de Ciencias Sociales - Número 71 (2017) - Universidad de Valparáíso - ISSN 0716-7725-Valparaíso, Chile 
Ahora bien, en el marco de la jurisprudencia comparada existe un precedente relativamente reciente, en el que el Tribunal Europeo de Derechos Humanos (TEDH) conoce el Caso Al Nashiri contra Polonia. En esta oportunidad, dos miembros de alto rango de Al Qaeda, demandaron al Gobierno de Polonia ante el TEDH, alegando que fueron torturados en una prisión clandestina de la Central de Inteligencia Americana (CIA) en el pueblo remoto de Stare Kiejkuty en Polonia durante 2002 y 2003. Sus abogados expusieron que Polonia violó varias disposiciones de la Convención Europea de Derechos Humanos (CEDH), cual prohíbe la tortura. El 24 de julio de 2014, el Tribunal determinó por unanimidad que contaba con prueba abundante y coherente que apuntaba a violaciones de los artículos 3 (Prohibición de la tortura), 5 (Derecho a la libertad y a la seguridad), 6 $\S 1$ (Derecho a un proceso equitativo), 8 (Derecho al respeto a la vida privada y familiar), 13 (Derecho a un recurso efectivo) y 38 (sobre la obligación de proporcionar todas las facilidades necesarias para el desarrollo eficaz de una investigación). Posteriormente, fue ratificado el fallo en apelación sobrevenida del gobierno polaco ${ }^{38}$.

Se confirma entonces el veredicto original, que estableció la complicidad del gobierno polaco en el programa secreto de entregas, detención e interrogación de la CIA, por lo cual recibió un pago en efectivo de $\$ 15$ millones de dólares estadounidenses. Como resultado, el Tribunal ordenó al gobierno de Polonia a: (1) presentar una investigación comprensiva y contundente sobre los hechos ocurridos en su territorio (como primer paso para procesar a funcionarios polacos que permitieron el funcionamiento de la cárcel); (2) procesar criminalmente a los responsables; (3) solicitar garantías por parte del gobierno estadounidense de que no condenará capitalmente a las dos víctimas, quienes se encuentran recluidas en la cárcel de Guantánamo; y (4) pagar a los afectados un monto ascendente a 230.000 euros $^{39}$. A su vez, el Tribunal Europeo de Derechos Humanos se alzó como el primer

38. Corte Europea de Derechos Humanos, Caso Al Nashiri Vs Polonia (Aplicación $\mathrm{N}^{\circ}$ 28761/11), Sección Cuarta. Sentencia final del 16 de febrero de 2015. 
foro judicial internacional de protección de los derechos humanos, en condenar a un Estado por su rol en este programa, ideado y diseñado por un país interesado en el exterminio de terroristas, y como se puede crear una estructura paralela de impunidad absoluta.

Lo que habría que resaltar de este procedente para nuestros efectos -independientemente de la variable política en sentido estricto- - radica en que estamos ante una obligación impuesta del deber de procesar a los responsables de este acto lesivo a los derechos humanos, aún si media una suerte de "favor mercenario", requerido por un tercer Estado. Es decir, nos encontramos ante un caso en el que el Estado sancionado, sirve como puente y facilitador de la actividad lesiva a individuos, cuyo interés por su tortura es requerido desde afuera; teniendo la única obligación de prestar su territorio para cometer el ilícito. Si hacemos una lectura a este tipo de posibilidades en nuestro orden latinoamericano, nos vamos a encontrar que la época de la Guerra Fría, marcó una coyuntura en la que los gobiernos dictatoriales del Cono Sur (Chile, Argentina, Brasil, Paraguay, Uruguay y Bolivia principalmente), crearon la denominada "Operación o Plan Cóndor" con participación de los Estados Unidos, llevada a cabo en las décadas de 1970 y 1980. Esta coordinación implicó, oficialmente, «el seguimiento, vigilancia, detención, interrogatorios con tortura, traslados entre países y desaparición o muerte de personas consideradas por dichos regímenes como "subversivas del orden instaurado" o contrarias al pensamiento político o ideológico opuesto, o no compatible con el gobierno de los Estados Unidos y por tanto con las dictaduras militares de la región».

Quizás una de las sentencias que más recogen esta penosa y represiva trama histórica en la Corte Interamericana, fue el Caso Goiburú y otros Vs. Paraguay ${ }^{40}$. De igual manera, en el denominado Caso Gelman Vs Uruguay, el Alto Tribunal, que analiza la situación de la desaparición de la nieta del poeta Juan Gelman, se aborda con mucha secuencia y base documental, el entramado de la denominada "Operación Cóndor" en Sudamérica ${ }^{41}$.

40. La existencia de la "doctrina de seguridad nacional” y del Plan Cóndor ya ha sido reconocida por la Corte Interamericana de Derechos Humanos en Corte IDH. Caso Goiburú y otros Vs. Paraguay párrs. 61.5 a 61.8.

41. Corte IDH. Caso Gelman Vs. Uruguay. Fondo y reparaciones. Sentencia del 24 de febrero del 2011. Serie C No 221, véanse los párrs. 41 al 48.

Revista de Ciencias Sociales - Número 71 (2017) - Universidad de Valparáíso - ISSN 0716-7725-Valparaíso, Chile 


\section{Obligación estatal de sancionar violaciones de derechos humanos cometidas por particulares con la aquiescencia del Estado}

Un asunto que es digno de mencionar, es el que atañe a la acción de los terceros no estatales, que perpetran un ilícito en materia de derechos humanos. Es el caso de los denominados paramilitares o escuadrones de acción civil, que fueron conformados en varios países latinoamericanos, al alero y consentimiento de los respectivos estados, quienes dieron soporte logístico y económico para su proliferación. Para el caso concreto de un país como Guatemala, la Comisión para el Esclarecimiento Histórico, señala que las fuerzas del Estado en asocio con los grupos paramilitares afines, fueron responsables de más del noventa por ciento, de las violaciones documentadas por la comisión ${ }^{42}$.

Precisamente en los anales jurisprudenciales de la Corte Interamericana, nos vamos a encontrar contenciosos contra el citado país -Blake, Paniagua Morales_, en los que grupos particulares cometen violaciones a los derechos humanos por influencia y adiestramiento brindado por el Estado ${ }^{43}$. Estos asuntos tienen la particularidad de constituirse en violaciones llevadas a cabo por particulares, cuyo patrocinio, logística y adiestramiento corrió por cuenta del citado gobierno, para repeler y aniquilar a ciertos grupos de la sociedad - principalmente activistas políticos de izquierda y población excluida socialmente como niños de la calle, como fue el Caso Villagrán Morales-. En el caso Blake se condena al citado país por la muerte de un periodista norteamericano, el cual fue incluso enterrado para que no se encontraran sus restos. La acción delictiva fue llevada a cabo por Patrullas de Acción

42. RODRÍGUEZ, Alejandro y ORTIZ, María José: Impunidad, Instituto de Estudios Comparados en Ciencias Penales de Guatemala. Editores Siglo veintiuno, primera edición, Ciudad de Guatemala, 2004. P. 3.

43. Este extracto es tomado con modificaciones más actualizadas, de nuestro artículo, CHACÓN, Alfonso: "Alcances de la Responsabilidad Penal Individual en el sistema interamericano". En: La Corte Interamericana de Derechos Humanos a veinticinco años de su funcionamiento. Instituto de Investigaciones Jurídicas, Universidad Nacional Autónoma de México, primera edición, 2007. Pp. 134-137.

Facultad de Derecho y Ciencias Sociales - Universidad de Valparaíso - Chile 
"Deberes y obligaciones de los Estados para combatir la impunidad a la luz...

Civil $(\mathrm{PAC})^{44}$ y en ese sentido la Corte Interamericana establece lo siguiente:

“...al contrario de lo que alegó Guatemala, las patrullas civiles actuaban efectivamente como agentes del Estado durante la época en que ocurrieron los hechos relevantes al presente caso (supra párr. 52. p)). Dicha conclusión se confirma con la abundante información y documentación disponible de diversas entidades, inclusive órganos de supervisión internacional de los derechos humanos (...) con fundamento en las pruebas examinadas y teniendo en cuenta los alegatos de las partes, la Corte considera probado que, en la época de los hechos relevantes del presente caso, las patrullas civiles tenían una relación institucional con el Ejército, realizaban actividades de apoyo a las funciones de las fuerzas armadas y, aún más, recibían recursos, armamento, entrenamiento y órdenes directas del Ejército guatemalteco y operaban bajo su supervisión, y a esas patrullas se les atribuían varias violaciones de derechos humanos, incluyendo ejecuciones sumarias y extrajudiciales y desapariciones forzadas de personas (supra párr. 52. p.) ${ }^{45}$.

El otro asunto sonado fue el de Paniagua Morales o conocido también como el de la Panel Blanca. Entre junio de 1987 y febrero de 1988 se produjeron en Guatemala detenciones arbitrarias calificadas como secuestros acompañadas de maltratos y torturas y, en algunos casos,

44. Sobre este concepto véase Unidad Revolucionaria Nacional Guatemalteca (URNG) “Cuatro Años de Gobierno Democratacristiano”, (Guatemala, 1990). Págs. 9 y 10.

45. Corte IDH, Caso Blake Vs Guatemala, párr. 75. A mayor abundamiento de pruebas la sentencia aduce que "Esa relación institucional queda de manifiesto en el mismo decreto de creación de los Comités de Defensa Civil (CDC), así como en los Acuerdos de Paz de Guatemala de 1996 que, en este último caso, establecen que los CDC, "incluyendo aquellos que se desmovilizaron con anterioridad, cesarán toda relación institucional con el Ejército de Guatemala y no serán reconvertidos de manera que se restituya esta relación" (subrayado no es del original)" párr. 77.

Revista de Ciencias Sociales - Número 71 (2017) - Universidad de Valparáíso - ISSN 0716-7725-Valparaíso, Chile 
de privación de la vida, todos cometidos por individuos que operaban en paneles blancas polarizadas y sin placas. Al respecto, el fallo de la Corte Interamericana adujo que el gobierno guatemalteco, no contradijo que los actos fueran realizados por agentes de la Guardia de Hacienda - principales sospechosos-y más bien adujo que los ilícitos de privación de libertad y asesinato fueron efectuados por delincuentes comunes y no por sus agentes, por lo que no sería responsable de ellos ${ }^{46}$. Se llegó a sustentar que si los ilícitos eran cometidos por personeros no identificados, entonces no se podía establecer la responsabilidad del gobierno de Guatemala, ya que esos actos podrían ser provocados por particulares. Continúa la sentencia acotando para lo que interesa, lo siguiente:

“91. Para establecer que se ha producido una violación de los derechos consagrados en la Convención, no se requiere determinar, como ocurre en el derecho penal interno, la culpabilidad de sus autores o su intencionalidad y tampoco es preciso identificar individualmente a los agentes a los cuales se atribuye los hechos violatorios. Es suficiente la demostración de que ha habido apoyo o tolerancia del poder público en la infracción de los derechos reconocidos en la Convención. Además, también se compromete la responsabilidad internacional del Estado cuando éste no realice las actividades necesarias, de acuerdo con su derecho interno, para identificar y, en su caso, sancionar a los autores de las propias violaciones".

En todo caso, el Tribunal estimó un modus operandi en donde los autores de dichas faltas siguieron patrones de vestimenta similares: tipo militar y hasta civil; actuaron con plena libertad e impunidad; los vehículos de uso que eran paneles etc. ${ }^{47}$ y eso fue suficiente para sancionar al Estado demandado como responsable. Tenemos entonces un

46. Corte IDH, Caso de la "Panel Blanca" (Paniagua Morales y otros) Vs

Guatemala, párr. 92.

47. Corte IDH, Caso Paniagua Morales y otros Vs Guatemala, párr. 93.

Facultad de Derecho y Ciencias Sociales - Universidad de Valparaíso - Chile 
patrón en ambos casos, en donde se hace uso de sujetos activos no estatales, con la finalidad de diluir la responsabilidad internacional del Estado. Por ello la trascendencia de estos veredictos radica en que la Corte Interamericana hace extensiva la responsabilidad aún por actos de particulares cuyo accionar sea resultado de la influencia; adiestramiento; complacencia o simplemente aquerencia del poder estatal.

A manera de glosa, el Tribunal ha reiterado que, según las normas del derecho sobre la responsabilidad internacional del Estado aplicables en el Derecho Internacional de los Derechos Humanos, la acción u omisión de cualquier autoridad pública constituye un hecho imputable al Estado que compromete su responsabilidad en los términos previstos en la Convención Americana ${ }^{48}$. En definitiva, para establecer que se ha producido una violación de los derechos consagrados en la Convención no se requiere determinar, como ocurre en el derecho penal interno, la culpabilidad de sus autores o su intencionalidad y tampoco es preciso identificar individualmente a los agentes a los cuales se atribuyen los hechos violatorios ${ }^{49}$. Como hemos visto y analizado, los agentes infractores o sujetos activos, pueden ser tanto funcionarios públicos como particulares y en el caso de estos últimos, con la anuencia y beneplácito del Estado.

\section{Imposibilidad de aplicación de mecanismos legales que favorezcan la impunidad de los eventuales responsables}

Un asunto que es necesario acotar en el marco de los análisis jurisprudenciales que estamos llevando a cabo, consiste en determinar

48. La doctrina se deriva del Caso Velásquez Rodríguez Vs. Honduras, párr. 164; y se ha reiterado en otros precedentes: Corte IDH. Caso Perozo y otros Vs. Venezuela. Excepciones Preliminares, Fondo, Reparaciones y Costas. Sentencia de 28 de enero de 2009. Serie C No 195, párr. 120, y Corte IDH. Caso Anzualdo Castro Vs. Perú. Excepción Preliminar, Fondo, Reparaciones y Costas. Sentencia de 22 de septiembre de 2009. Serie C No 202, párr. 37.

49. Corte IDH. Caso De la Masacre de las Dos Erres Vs. Guatemala, Excepción preliminar, fondo, reparaciones y costas. Sentencia de 24 de noviembre de 2009, Serie C No 21, párr. 197.

Revista de Ciencias Sociales - Número 71 (2017) - Universidad de Valparáíso - ISSN 0716-7725-Valparáiso, Chile 
los efectos nocivos que conllevan prácticas institucionalizadas para favorecer la impunidad. En ese sentido, figuras de extinción de la pena o la sanción, como la prescripción; la amnistía etc., no son bien vistas por la jurisprudencia de la Corte Interamericana de Derechos Humanos. A manera de ejemplo, en referencia a la posible prescripción en la causa pendiente a nivel de derecho interno, la Corte Interamericana señaló en el Caso Bulacio vs. Argentina, que son inadmisibles las disposiciones de prescripción o cualquier obstáculo de derecho interno mediante el cual se pretenda impedir la investigación y sanción de los responsables de las violaciones de derechos humanos ${ }^{50}$.

Sin embargo, estimamos que no es sino hasta en el Caso Barrios Altos, que se sientan las bases jurisprudenciales de la incongruencia de las leyes de amnistía, para no enjuiciar a efectivos estatales, perpetuadores de violaciones a los derechos humanos. Concretamente con motivo de un asesinato perpetuado por miembros que trabajaban para inteligencia militar; siendo componentes del Ejército peruano que actuaban en el "escuadrón de eliminación" llamado "Grupo Colina", que llevaba a cabo su propio programa antisubversivo; el Congreso peruano sancionó una ley de amnistía, la Ley No 26479, que exoneraba de responsabilidad a los militares, policías, y también a civiles, que hubieran cometido, entre 1980 y 1995, violaciones a los derechos humanos o participado en esas violaciones. El Congreso peruano aprobó una segunda ley de amnistía, la Ley No 26492, la cual declaró que la amnistía no era "revisable" en sede judicial y que era de obligatoria aplicación (párrafo 2 de la sentencia).

El Tribunal Interamericano enfatizó que las leyes de auto amnistía conducen a la indefensión de las víctimas y a la perpetuación de la impunidad al obstaculizar la investigación de violaciones graves a derechos humanos como la tortura, las ejecuciones sumarias, extralegales $\mathrm{o}$ arbitrarias, y las desapariciones forzadas, todas ellas prohibidas por contravenir derechos inderogables, como son el derecho de acceso a la justicia, el derecho de los familiares a conocer la verdad y el derecho a recibir la reparación correspondiente ${ }^{51}$. $\mathrm{Al}$ respecto, las leyes de amnistía

50. Corte IDH. Caso Bulacio Vs. Argentina, párr. 116.

51. FERRER, Eduardo, ob. cit. P. 75.

Facultad de Derecho y Ciencias Sociales - Universidad de Valparaíso - Chile 
no solo son incompatibles con la Convención, y por lo tanto carecen de efectos jurídicos y “...no pueden seguir representando un obstáculo para la investigación de los hechos que constituyen este caso ni para la identificación y el castigo de los responsables, ni puedan tener igual o similar impacto respecto de otros casos de violación de los derechos consagrados en la Convención Americana acontecidos en el Perú" ${ }^{\prime 2}$.

Cronológicamente vamos a referirnos a una serie de precedentes que desde nuestra perspectiva, han reiterado y aportado jurisprudencialmente a la construcción del criterio en estudio. Empezamos indicando que en el Caso de la Comunidad Moiwana (2005), el Alto Tribunal Interamericano establece que:

"ninguna ley ni disposición de derecho interno —incluyendo leyes de amnistía y plazos de prescripción - puede impedir a un Estado cumplir la orden de la Corte de investigar y sancionar a los responsables de violaciones de derechos humanos. En particular, las disposiciones de amnistía, las reglas de prescripción y el establecimiento de excluyentes de responsabilidad que pretendan impedir la investigación y sanción de los responsables de las violaciones graves de los derechos humanos — como las del presente caso, ejecuciones sumarias, extrajudiciales o arbitrarias - son inadmisibles, ya que dichas violaciones contravienen derechos inderogables reconocidos por el Derecho Internacional de los Derechos Humanos" ${ }^{\text {33 }}$.

Ese mismo año, en la Masacre de Mapiripán no solo se vuelve a decretar la inconveniencia de las leyes que patrocinen la impunidad; sino que además las califica de "inaceptables" ${ }^{4}$, a la vez que aduce lo siguiente: "El Tribunal reitera que la obligación del Estado de investigar

52. Corte IDH, Caso Barrios Altos Vs Perú, párr. 44.

53. Corte IDH. Caso de la Comunidad Moiwana Vs. Surinam. Excepciones Preliminares, Fondo, Reparaciones y Costas. Sentencia 15 de junio de 2005. Serie C No 124, párr. 206.

54. Corte IDH. Caso de la “Masacre de Mapiripán” Vs. Colombia, párr. 304.

Revista de Ciencias Sociales - Número 71 (2017) - Universidad de Valparáíso - ISSN 0716-7725-Valparáiso, Chile 
de manera adecuada y sancionar, en su caso, a los responsables, debe cumplirse diligentemente para evitar la impunidad y que este tipo de hechos vuelvan a repetirse".

Para el año 2006, se suscitan dos antecedentes de suma importancia; el primero es el Caso Baldeón García y en lo que interesa, reitera que ninguna ley ni disposición de derecho interno - incluyendo leyes de amnistía y plazos de prescripción - puede impedir a un Estado, cumplir la orden de la Corte de investigar y sancionar a los responsables de violaciones de derechos humanos. Aduce tajantemente lo siguiente:

"En particular, las disposiciones de amnistía, las reglas de prescripción y el establecimiento de excluyentes de responsabilidad que pretendan impedir la investigación y sanción de los responsables de las violaciones graves de los derechos humanos son inadmisibles, ya que dichas violaciones contravienen derechos inderogables reconocidos por el Derecho Internacional de los Derechos Humanos" ${ }^{55}$.

De la misma manera, considera que un proceso rectilíneo es el mejor antídoto para contar con un proceso encausado hacia la justicia, evitando la impunidad. Es así como teniendo en cuenta los factores de desigualdad real de quienes son llevados ante la justicia, se hace obligatorio adoptar medidas de compensación que contribuyan a reducir o eliminar los obstáculos y deficiencias que impidan o reduzcan la defensa eficaz de los propios intereses.

Prosigue diciéndonos la sentencia que "Si no existieran esos medios de compensación, ampliamente reconocidos en diversas vertientes del procedimiento, difícilmente se podría decir que quienes se encuentran en condiciones de desventaja disfrutan de un verdadero acceso a la justicia y se benefician de un debido proceso legal en condiciones de igualdad con quienes no afrontan esas desventajas" ${ }^{26}$.

55. Corte IDH. Caso Baldeón García Vs. Perú. Fondo, Reparaciones y Costas. Sentencia de 6 de abril de 2006. Serie C No 147, párr. 201.

56. Corte IDH. Caso Baldeón García Vs. Perú, párr. 202.

Facultad de Derecho y Ciencias Sociales - Universidad de Valparaíso - Chile 
El otro antecedente se circunscribe al Caso de las Masacres de Ituango contra Colombia, en cuyo antecedente la Corte adujo lo siguiente:

“402. La Corte reitera su jurisprudencia constante en el sentido de que ninguna ley ni disposición de derecho interno puede impedir a un Estado cumplir con la obligación de investigar y sancionar a los responsables de violaciones de derechos humanos. En particular, son inaceptables las disposiciones de amnistía, las reglas de prescripción y el establecimiento de excluyentes de responsabilidad que pretendan impedir la investigación y sanción de los responsables de las violaciones graves de los derechos humanos, como las del presente caso. El Tribunal reitera que la obligación del Estado de investigar de manera adecuada y sancionar, en su caso, a los responsables, debe cumplirse diligentemente para evitar la impunidad y que este tipo de hechos vuelvan a repetirse" $" 57$.

\section{Derecho de los familiares de conocer la verdad}

A lo largo de su jurisprudencia, la Corte Interamericana ha reconocido el derecho de los familiares de conocer la verdad, con relación a sus seres queridos que hayan sido víctimas ${ }^{58}$. Estamos ni más ni menos, ante el ineludible derecho de acceder a la justicia, que no significa solamente que haya un proceso que busca castigar a los culpables, sino que conlleva a un derecho de participar, hasta cierto grado en él. Así lo ha

57. Corte IDH. Caso de las Masacres de Ituango Vs. Colombia. Excepción Pre-

liminar, Fondo, Reparaciones y Costas. Sentencia de 1 de julio de 2006. Serie C No 148, párr. 402.

58. Los antecedentes podemos encontrarlos cronológicamente en Corte IDH. Velásquez Rodríguez Vs Honduras, párr. 181; Corte IDH. Caso Bámaca Velásquez Vs Guatemala, párr. 70; Corte IDH. Caso Barrios Altos Vs Perú, párr. 200201. Cfr: Pude encontrase igualmente una importante referencia, en Corte IDH, Caso Durand y Ugarte Vs Perú, Fondo. Sentencia del 16 de agosto de 2000, Serie C Nº 68, párr. 143.

Revista de Ciencias Sociales - Número 71 (2017) - Universidad de Valparáíso - ISSN 0716-7725-Valparáiso, Chile 
entendido la jurisprudencia de la instancia regional, cuando analiza el derecho al debido proceso desde una perspectiva amplia:

“...del artículo $8 \ldots$ se desprende que las víctimas de las violaciones de los derechos humanos, o sus familiares, deben contar con amplias posibilidades de ser oídos y actuar en los respectivos procesos, tanto en procura del esclarecimiento de los hechos y del castigo de los responsables, como en busca de una debida reparación" ${ }^{59}$.

Esta visualización en el sentido que tratándose del derecho a la vida, una violación a esta garantía constituye para los familiares, el "derecho de acceso a la justicia", ha sido reiterada posteriormente por la misma Corte Interamericana. Así lo ha manifestado su jurisprudencia en el caso de la Masacre de La Rochela ${ }^{60}$, en el entendido que nadie más que la propia parentela, está interesada en esclarecer lo acaecido y cualquier obstáculo a este anhelo, se constituye en una flagrante violación contraria a la Convención Americana de Derechos Humanos.

Por otra parte, en el Caso Gómez Palomino vs Perút ${ }^{61}$, la Corte Interamericana es del criterio de que los familiares de las víctimas de graves violaciones de derechos humanos, tienen el derecho a conocer la verdad; y al respecto indicó:

59. Corte IDH, Caso Villagrán Morales Vs Guatemala, párr. 227.

60. Corte IDH. Caso de la Masacre de La Rochela Vs. Colombia. Fondo, Reparaciones y Costas. Sentencia de 11 de mayo de 2007. Serie C $N^{0} 163$, párr. 224.

61. El caso se refiere a la responsabilidad internacional del Estado por la desaparición forzada de Santiago Gómez Palomino por parte de agentes militares, así como la falta de investigación y sanción de los responsables. Se alegó violación de los Artículos 1 (Obligación de respetar los derechos), Artículo 2 (Deber de adoptar disposiciones de derecho interno), Artículo 25 (Protección Judicial), Artículo 4 (Derecho a la vida), Artículo 5 (Derecho a la Integridad Personal), Artículo 7 (Derecho a la libertad personal), Artículo 8 (Garantías Judiciales) de la CADH. En Corte IDH, Caso Gómez Palomino vs Perú. Fondo, Reparaciones y Costas. Sentencia del 22 de noviembre de 2005. Serie C No 136, párr. 78.

Facultad de Derecho y Ciencias Sociales - Universidad de Valparaíso - Chile 
"La Corte ha reiterado que los familiares de víctimas de graves violaciones de derechos humanos tienen el derecho a conocer la verdad sobre estas violaciones. Este derecho a la verdad, al ser reconocido y ejercido en una situación concreta, constituye un medio importante de reparación para la víctima y sus familiares y da lugar a una expectativa que el Estado debe satisfacer. Por otra parte, el conocer la verdad facilita a la sociedad peruana la búsqueda de formas de prevenir este tipo de violaciones en el futuro"62.

Nótese que la sentencia homologa el derecho familiar de conocer lo sucedido, como una forma clara de reparación o resarcimiento, por el daño causado. La angustia, la desesperación de no tener conocimiento de lo sucedido por parte del núcleo familiar, genera una situación lesiva para el entorno inmediato de la víctima o las víctimas.

Además, se establecen dos obligaciones positivas según el anterior fragmento jurisprudencial: la primera consiste en que el Estado debe satisfacer todas las situaciones en las que solicite conocer la verdad de lo sucedido, y paralelamente; el esclarecimiento de los hechos constituye en una manera aleccionadora y preventiva, con la finalidad de no incurrir nuevamente en estos desaciertos. Estamos ante la $<<$ memoria histórica $>>$ que debe ser ventilada y conocida, con la finalidad de no volver a cometer las violaciones a los derechos humanos y sobre todo, que sirva de parámetro de construcción de justiciabilidad ante los infractores, sean poderes públicos o particulares.

En el veredicto del Caso de la Masacre de Mapiripán, la Corte Interamericana dispuso y reitera que "el Estado está obligado a combatir esta situación de impunidad por todos los medios disponibles, ya que ésta propicia la repetición crónica de las violaciones de derechos humanos y la total indefensión de las víctimas y de sus familiares, quienes tienen derecho a conocer la verdad de los hechos" (énfasis nuestro) ${ }^{63}$. Se hace mención al carácter de indefensión que se les genera

\footnotetext{
62. Corte IDH, Caso Gómez Palomino Vs Perú, párr. 78.

63. Corte IDH. Caso de la “Masacre de Mapiripán” Vs. Colombia, párr. 297.
} 
a los familiares de las víctimas, puesto que son quienes deben de continuar con la búsqueda de la verdad y en ese imperativo, el poder jurisdiccional interno debe de proporcionar los elementos investigativos y de concatenación de situaciones fácticas, que permitan la atribución de responsabilidades.

Para finalizar, es muy evidente que el derecho de los familiares se asume como un derecho autónomo e independiente, legitimado por los lazos de consanguinidad o afinidad. Esta situación implica desde una óptica objetiva, no solo una titularidad procesal y moral, sino además exige un correlativo deber de investigar, juzgar y reparar por parte de Estado a quienes sucedan en vida, a aquellos que han sido víctimas.

\section{Consideraciones finales}

Llegados a esta fase culminante del trabajo desplegado, se ha tratado de hacer un recorrido centrados en determinar la relación causal entre el derecho a la verdad como garantía exigible por el Estado de Derecho y conexamente los familiares; para que todos aquellos Estados infractores, no sigan alimentando la estela de impunidad surgida por la deplorable omisión de investigar, juzgar y sancionar a los culpables de tales vejámenes.

Se ha llevado a cabo un intento de sistematización pormenorizado de más de cuarenta sentencias de la Corte Interamericana de Derechos Humanos, que abordan la relación causal expuesta. Cada uno de los descriptores, ha pretendido darle una noción de integralidad al fenómeno de la impunidad, su incidencia en obstaculizar la verdad legal, familiar y por ende social.

La jurisprudencia nos ha mostrado una serie de claves y líneas interpretativas tanto genéricas como específicas, que en última instancia nos llevan a concluir que la impunidad y todo lo nefasto que dicha condición encierra, se constituye en una práctica contraria a la CADH. Se espera que esta delimitación jurídica de lo que se entiende por impunidad, contribuya a perfilar los obstáculos y vicisitudes que tiene el Estado de Derecho, en su desarrollo y devenir actual en América Latina prioritariamente.

Facultad de Derecho y Ciencias Sociales - Universidad de Valparaíso - Chile 
"Deberes y obligaciones de los Estados para combatir la impunidad a la luz...

Es el momento de gestar las bases de una verdadera cultura de legalidad, que permita a la institucionalidad responder al clamor ciudadano de justicia. Nuestras sociedades actuales y futuras, no merecen vivir con semejante y agobiante flagelo.

\section{BIBLIOGRAFÍA}

CHACÓN MATA, Alfonso: "Alcances de la Responsabilidad Penal Individual en el sistema interamericano" 115-142. En: La Corte Interamericana de Derechos Humanos a veinticinco años de su funcionamiento, Editado por Manuel Becerra, Instituto de Investigaciones Jurídicas, Universidad Nacional Autónoma de México, primera edición, 2007.

CHACÓN MATA, Alfonso: “La 'Cosa Juzgada Fraudulenta' en la jurisprudencia de la Corte Interamericana de Derechos Humanos: Implicaciones para el Estado de Derecho Contemporáneo”. En: Revista Prolegómenos, Derechos y Valores, Centro de Investigaciones de la Facultad de Derecho de la Universidad Militar de Nueva Granada, Bogotá, vol. XVIII No 35, primer semestre, 2015.

FERRAJOLI, Luigi: Derechos y garantías: La ley del más débil. Editorial Trotta, colección estructuras y procesos, séptima edición, Madrid, 2010.

FERRER MAC GREGOR, Eduardo: "Las siete principales líneas jurisprudenciales de la Corte Interamericana de Derechos Humanos aplicable a la justicia penal”. En: Revista Instituto Interamericano de Derechos Humanos, Edición especial en homenaje a Elizabeth Odio Benito, San José, Enero-Junio, 2014.

GONZÁLEZ POBLETE, Alejandro: "La superación de la impunidad como requisito del Estado de Derecho". En: Presente y futuro de los derechos humanos: Ensayos en honor a Fernando Volio Jiménez, editado por Lorena González Volio, Instituto Interamericano de Derechos Humanos-IIDH, San José, 1998. Pp. 53-72.

MATAROLLO, Rodolfo: "Las comisiones de la verdad". En: Verdad y Justicia. Homenaje a Emilio F. Mignone, Instituto Interamericano de Derechos Humanos, IIDH, San José, 2001. Pp. 130-171.

Revista de Ciencias Sociales - Número 71 (2017) - Universidad de Valparáíso - ISSN 0716-7725-Valparáiso, Chile 
MONTOYA CÉSPEDES, Nicolás: "Indicadores cuantitativos del cumplimiento de las obligaciones positivas derivadas de la Convención Americana sobre Derechos Humanos”. En: Manual de derechos Humanos y Politicas Públicas, editado por Laurence BurgorgueLarsen, Antonio Maués y Beatriz Sánchez Mojica, Red de Derechos Humanos y Educación Superior, Bogotá, 2014. Pp. 131-191

NIKKEN, Pedro: "La pobreza en la perspectiva de los derechos humanos y la democracia”, 157-208. En: ¿Quién responde por los derechos humanos de las poblaciones más pobres en América Latina y El Caribe?, editado por Pedro Nikken et al, Instituto Interamericano de Derechos Humanos, San José, 2012.

ORGANIZACIÓN DE LAS NACIONES UNIDAS (ONU), Conferencia Mundial de Derechos Humanos: Declaración y Programa de Acción de Viena, 14 a 25 de junio de 1993, A/CONF.157/23, español, 12 de julio de 1993.

ORGANIZACIÓN DE NACIONES UNIDAS, Asamblea General: Promoción de la verdad, la justicia, la reparación y las garantías de no repetición. Informe del Relator Especial sobre la promoción de la verdad, la justicia, la reparación y las garantías de no repetición, Pablo de Greiff, A/68/345, Español, Original: inglés, 23 de agosto de 2013.

ORGANIZACIÓN DE NACIONES UNIDAS, Asamblea General:

Promoción de la verdad, la justicia, la reparación y las garantías de no repetición. Informe del Relator Especial sobre la promoción de la verdad, la justicia, la reparación y las garantías de no repetición, Pablo de Greiff, A/69/518, Español Original: inglés, 14 de octubre de 2014. PROGRAMA DE LAS NACIONES UNIDAS PARA EL DESARROLLO (PNUD): Informe sobre Desarrollo Humano 2000, publicado por PNUD, Ediciones Mundi Prensa, Madrid-Barcelona-México, 2000. RIVERO SÁNCHEZ, Juan Marcos: Constitución, Derechos Fundamentales y Derecho Privado. Medellín-San José Costa Rica: Biblioteca Jurídica Diké, Ediciones Areté, 2001.

RODRÍGUEZ BARILLAS, Alejandro y ORTIZ, María José: Impunidad. Editores Siglo veintiuno, Instituto de Estudios Comparados en Ciencias Penales de Guatemala, Ciudad de Guatemala, primera edición, julio 2004.

RODRÍGUEZ GARAVITO, César y RODRÍGUEZ FRANCO, Diana: Juicio a la exclusión: El impacto de los tribunales sobre los derechos

Facultad de Derecho y Ciencias Sociales - Universidad de Valparaíso - Chile 
sociales en el Sur Global. Siglo veintiuno editores S.A.-Dejusticia, Colección derecho y política, Buenos Aires, 2015.

RODRÍGUEZ RESCIA, Víctor: Curso de Derechos Humanos. Investigaciones Jurídicas S.A., San José Costa Rica, 2016.

TOHARIA, José Juan: "Cultura de legalidad y Buena Justicia”. En: Cultura de la legalidad en Iberoamérica: desafíos y experiencias, editado por Isabel Wences et al. Facultad Latinoamericana de Ciencias Sociales, primera edición, San José Costa Rica, 2014. Pp. 119-135.

UNIDAD REVOLUCIONARIA NACIONAL GUATEMALTECA (URNG). Cuatro Años de Gobierno Democratacristiano. Guatemala, enero 1990.

WENCES, Isabel y SAUCA, José María: "Cultura de la legalidad: proyecto y movimiento": En: Cultura de la legalidad en Iberoamérica: desafíos y experiencias, editado por Isabel Wences et al. Facultad Latinoamericana de Ciencias Sociales, primera edición, San José Costa Rica, 2014. Pp. 17-45.

\section{JURISPRUDENCIA}

Corte IDH. Caso Velásquez Rodríguez Vs. Honduras. Fondo. Sentencia del 29 de julio de 1988. Serie C No 04.

Caso de la "Panel Blanca" (Paniagua Morales y otros) Vs. Guatemala. Fondo y reparaciones. Sentencia del 8 de marzo de 1998. Serie C N 37.

Caso Blake Vs. Guatemala. Reparaciones y Costas. Sentencia de 22 de enero de 1999, Serie C No 48.

Caso Loayza Tamayo Vs. Perú, Excepciones, fondo y sentencia. Sentencia 27 de noviembre de 1998. Serie C, número 42.

Caso Suárez Rosero Vs. Ecuador. Reparaciones y Costas. Sentencia de 20 de enero de 1999, Serie C No 51.

Caso Castillo Petruzzi y otros Vs. Perú. Fondo, Reparaciones y Costas. Sentencia de 30 de mayo de 1999. Serie C No 52.

Caso Durand y Ugarte Vs Perú, Fondo. Sentencia del 16 de agosto de 2000, Serie C No 68.

Caso Bámaca Velásquez Vs. Guatemala. Fondo. Sentencia de 25 de noviembre de 2000. Serie C No 70 .

Revista de Ciencias Sociales - Número 71 (2017) - Universidad de Valparáíso - ISSN 0716-7725-Valparaíso, Chile 
Caso del Tribunal Constitucional Vs. Perú. Fondo, Reparaciones y Costas. Sentencia de 31 de enero de 2001. Serie C No 71.

Caso Ivcher Bronstein Vs. Perú. Fondo, Reparaciones y Costas. Sentencia de 6 de febrero de 2001. Serie C No 74.

Caso Barrios Altos Vs. Perú. Fondo. Sentencia de 14 de marzo de 2001. Serie C No 75.

Corte IDH. Caso de los "Niños de la Calle" (Villagrán Morales y otros vs. Guatemala). Reparaciones (Art. 63.1 de la Convención Americana sobre Derechos Humanos). Sentencia de 26 mayo de 2001. Serie C No 77.

Caso Bámaca Velásquez Vs. Guatemala. Reparaciones y Costas. Sentencia de 22 de febrero de 2002. Serie C No 91.

Caso Las Palmeras Vs. Colombia. Reparaciones y Costas. Sentencia de 26 noviembre de 2002. Serie C No 96.

Caso Juan Humberto Sánchez Vs. Honduras. Excepción Preliminar, Fondo, Reparaciones y Costas. Sentencia de 7 de junio de 2003. Serie C No 99.

Caso Bulacio Vs. Argentina. Fondo, reparaciones y costas. Sentencia de 18 de septiembre de 2003. Serie C No 100.

Caso Maritza Urrutia Vs. Guatemala. Fondo, Reparaciones y Costas. Sentencia de 27 de noviembre de 2003. Serie C No 103. Caso Bulacio Vs. Argentina. Fondo, reparaciones y costas. Sentencia de 18 de septiembre de 2003. Serie C No 100.

Caso 19 Comerciantes Vs. Colombia. Fondo, Reparaciones y Costas. Sentencia de 5 de julio de 2004. Serie C No 109.

Caso de los Hermanos Gómez Paquiyauri Vs. Perú Fondo, Reparaciones y Costas. Sentencia de 8 de julio de 2004, Serie C $\mathrm{N}^{\circ} 110$.

Caso Carpio Nicolle y otros Vs. Guatemala. Fondo, Reparaciones y Costas. Sentencia de 22 de noviembre 2004. Serie C No 117. Caso Huilca Tecse Vs. Perú. Fondo, Reparaciones y Costas. Sentencia de 3 de marzo de 2005. Serie C No 121.

Caso de la Comunidad Moiwana Vs. Surinam. Excepciones Preliminares, Fondo, Reparaciones y Costas. Sentencia 15 de junio de 2005. Serie C No 124.

Facultad de Derecho y Ciencias Sociales - Universidad de Valparaíso - Chile 
Caso de la "Masacre de Mapiripán" Vs. Colombia. Fondo, Reparaciones y Costas. Sentencia de 15 de septiembre de 2005. Serie C N $\mathrm{N}^{\circ} 134$.

Caso Gómez Palomino vs Perú. Fondo, Reparaciones y Costas. Sentencia del 22 de noviembre de 2005. Serie C No 136.

Caso Baldeón García Vs. Perú. Fondo, Reparaciones y Costas. Sentencia de 6 de abril de 2006. Serie C No 147.

Caso de las Masacres de Ituango Vs. Colombia. Excepción Preliminar, Fondo, Reparaciones y Costas. Sentencia de 1 de julio de 2006. Serie C N ${ }^{\circ} 148$.

Caso Goiburú y otros Vs. Paraguay. Fondo, Reparaciones y Costas. Sentencia de 22 de septiembre de 2006. Serie C No 153.

Caso Almonacid Arellano y otros Vs. Chile. Excepciones Preliminares, Fondo, Reparaciones y Costas. Sentencia de 26 de septiembre de 2006. Serie C No 154.

Caso Vargas Areco Vs. Paraguay. Sentencia de 26 de septiembre de 2006. Serie C No 155.

Caso del Penal Miguel Castro Castro Vs. Perú. Fondo, Reparaciones y Costas. Sentencia de 25 de noviembre de 2006. Serie C $\mathrm{N}^{\circ} 160$.

Caso de la Masacre de La Rochela Vs. Colombia. Fondo, Reparaciones y Costas. Sentencia de 11 de mayo de 2007. Serie C $\mathrm{N}^{\circ} 163$.

Caso Zambrano Vélez y otros Vs. Ecuador. Fondo, Reparaciones y Costas. Sentencia de 4 de julio de 2007. Serie C No 166.

Caso Perozo y otros Vs. Venezuela. Excepciones Preliminares, Fondo, Reparaciones y Costas. Sentencia de 28 de enero de 2009. Serie C No 195.

Caso Anzualdo Castro Vs. Perú. Excepción Preliminar, Fondo, Reparaciones y Costas. Sentencia de 22 de septiembre de 2009. Serie $\mathrm{C} \mathrm{N}^{\circ} 202$.

Caso De la Masacre de las Dos Erres Vs. Guatemala, Excepción preliminar, fondo, reparaciones y costas. Sentencia de 24 de noviembre de 2009. Serie C No 211.

Caso Gelman Vs. Uruguay. Fondo y reparaciones. Sentencia del 24 de febrero del 2011. Serie C No 221. 
Caso Masacres de El Mozote y lugares aledaños Vs. El Salvador. Fondo, Reparaciones y Costas. Sentencia de 25 de octubre de 2012. Serie C No 252.

Caso García y Familiares Vs. Guatemala. Fondo Reparaciones y Costas. Sentencia de 29 noviembre de 2012. Serie C No 258.

Caso Masacre de Santo Domingo Vs. Colombia. Excepciones Preliminares, Fondo y Reparaciones. Sentencia de 30 de noviembre de 2012. Serie C No 259.

Caso Gutiérrez y Familia Vs. Argentina. Fondo, Reparaciones y Costas. Sentencia del 25 de noviembre del 2013. Serie C No 271. Caso Osorio Rivera y Familiares Vs. Perú. Excepciones Preliminares, Fondo, Reparaciones y Costas. Sentencia de 26 de noviembre de 2013. Serie C No 274.

Tribunal Europeo de Derechos Humanos. Caso Al Nashiri Vs Polonia (Aplicción $\mathrm{N}^{\circ}$ 28761/11), Sección Cuarta. Sentencia final del 16 de febrero de 2015. 